\title{
論文・資料
}

\section{昇華性染料感熱転写方式による電子スチルカメラ用 カラーハードコピー装置}

\author{
正会員 半 間 謙太郎 ${ }^{\dagger}, \quad$ 後 藤 敏 彦 ${ }^{\dagger}$ \\ 白 石 幹 夫 $^{\dagger}$
}

\begin{abstract}
あらまし 昇華性染料を用いた電子スチルカメラ用ハードコピー装置の試作につき, 主に連続階 調表現の観点から実験, 解析した結果を述べた．安定な連続階調印画には，感熱へッドの入力電 力, 基板温度, 印写ドラムとの位置, 押圧が重要なパラメータであることを明らかにし, これらと 印写濃度との関係を実験, 解析により定式化した。試作装置の印画画質は, 色の再現性, 階調特性 （各色 64 階調）共にモニタテレビ画面にほぼ対応したものであった。一方，印画サイズを手札判相 当 $(80 \times 98 \mathrm{~mm})$ とし, 分解能を 6 本 $/ \mathrm{mm}$ としたので, 明視距離では走查線構造も目立たず, 解像 感のあるハードコピーが得られた. カラー化は黄, マゼンタ, シアン 3 色面順次方式で行い, 絵素 数は各色 $480(\mathrm{~V}) \times 512(\mathrm{H})$ とした。プリント所要時間は約 1 分である.
\end{abstract}

\section{1. ま え がき}

電子スチルカメラは従来の銀塩フィルムの代りに， 超小型の磁気シートから成るビデオフロッピーに撮影 画像を記録し，モニ夕画面上に即時に再生できるとい う全く新しい考え方のスチルカメラであり，固体撮像 技術と高密度磁気記録技術を基盤としている ${ }^{122)}$.

本報告は，この電子スチルカメラの撮影ビデオ信号 を入力し , 必要に応じてカラーハードコピー化する装 置に関するものである. 文字あるいは図形の印写を主 目的とするプリンタと，ビデオ信号を高画質に印画す るいわゆるピクトリアルハードコピー用のプリンタの 最も大きな相異は，後者が忠実かつ高品質の連続階調 の調子再現を要求されることにある。連続階調印写を 実現する方式にはいろいろの方式 ${ }^{3)}$ が知られており， 従来の銀塩写真技術を応用するもの，インクジェット や感熱溶融転写インク等を用いて発色面積を制御する もの，あるいは本報告のように昇華性染料を塗付した カラーインクシートを用い, 感熱ヘッドで染料インク の昇華量を制御する方式 4 )5)等が知られている. 発色 面積で連続階調表現をする方式は，解像度を一定とす ると, 表現したい階調数を増すにつれて画像の 1 絵素

$\dagger$ 株式会社日立製作所 家電研究所

"Color Hard Copy Equipment for Electronic Still Camera System with Sublimation Dye Thermal Transfer Method" by Kentaro Hanma, Toshihiko Goto, and Mikio Shiraishi (Consumer Products Research Center, Hitachi Ltd., Tokyo)
に割当てる印写ドットの線密度と線数を増加せざるを 得ない。これに対し，昇華性染料熱転写方式は，感熱 ヘッドの発熱ドット毎に印加エネルギーを制御して連 続階調を表現できる。したがって, 面積階調方式に比 べて数分の 1 以下の線密度の感熱ヘッドを用いて画像 として好ましい階調かつ解像力のプリントが得られ， 特に印画サイズの小さなピクトリアルハードコピー装 置に適した方式といえる.

本論文は, この昇華染料熱転写方式のビデオプリン 夕の試作を, 主に安定な連続階調表現の観点から実 験, 解析した結果を述べたものである．試作したプリ ンタは, 電子スチルカメラの規格である水平解像度 $350 \mathrm{TV}$ 本の映像信号入力に対し, 明視距離で写真様 の解像感と調子再現を得ることを意識して印画サイズ $80 \times 98 \mathrm{~mm}$ (解像度 6 本 $/ \mathrm{mm}$ ), 絵素数 480 (垂直) $\times$ 512 (水平) 個とし, 各絵素につき黄, マゼンタ, シア ンの各色を 64 段階で連続階調表現させた. 印画所要 時間は約 1 分である。

\section{2. 印写条件の検討}

\section{1 昇華性染料熱転写方式}

昇華性染料熱転写方式の原理を図 1 に示す. 入力ビ デオ信号の振幅に対応した電流パルスが感熱ヘッドの 発熱素子 (抵抗体) で熱エネルギーに変換され, イン ク紙のインク層を加熱する．加熱されたインク層の昇 華性染料は気化して受像紙の受容層に転写して固着す る．この場合，感熱へッドに入力するエネルギーに対 


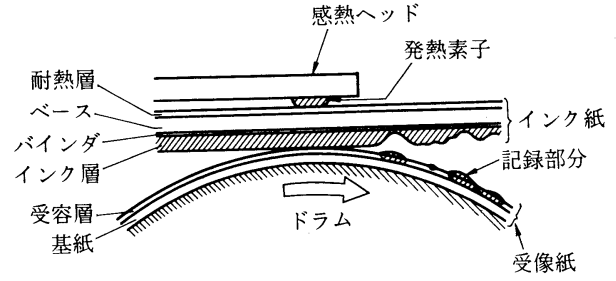

図 1 昇華性染料熱転写方式

Principle of sublimation dye thermal transfer method.

応して昇華し, 転写固着するインクの量が変化するの で, 発熱ドット毎の階調表現ができる。この場合, 転 写されたインクの反射濃度は, インク紙および受像紙 の特性, 感熱ヘッドの特性と駆動条件, 感熱へッドと ドラムの押圧力等に大きく依存する。したがって, 安 定かつ高能率な連続階調印写を行うための条件を求め ることが不可欠である.実験には，インク紙として背 面を耐熱処理した厚さ $6 \mu \mathrm{m}$ のポリエチレンテレフタ レート (PET) フィルムにシアン, マゼンタ, 黄の分 散染料を結着剂と共に各々面順次塗付(厚さ約 $1 \mu \mathrm{m}$ ) したものを用いた．受像紙は厚さ $150 \mu \mathrm{m}$ の合成紙を 基紙とし，これに厚さ $5 \sim 6 \mu \mathrm{m}$ のポリエステル系の 受容層を塗付したものである. 感熱へッドは分解能 6 本 $/ \mathrm{mm}$ の薄膜ラインヘッド（512 素子）を用いた。

\section{2 濃度のヘッド印加電圧依存性}

図 2 に印写の濃度測定例を示す。測定にはシアンイ ンクを用い, その補色濃度を濃度計により求めた。図 中の複数の特性曲線は, ヘッドの発熱体（抵抗值 $R$ $\Omega$, 印加電圧 $\left.V_{R}\right)$ 毎の消費電力 $P_{R}=V_{R}^{2} / R$ をパラメ ータとして測定した結果である.プリンタの設計にお いては, 特性曲線の非直線性を補正し最適な階調特性 を得る必要があるが,ここでは特性曲線の直線部分に 着目して濃度 $D$ と通電時間 $t_{\text {on }}$ との関係を形式的に 係数 $A$, 定数 $t_{0}, D_{0}$ を用いて表すと, 各々の曲線に ついて,

$$
D=A\left(t_{\text {on }}-t_{0}\right)-D_{0}
$$

さて，(1)式をもう少し見通しの良いものとするた め, 濃度 $D$ とへッドの入力電気エネルギー $E=P_{R}$ $t_{o n}$ との関係として書き改める.すなわち新しい係数 $B=A / P_{R}$ を使って,

$$
D=B\left(E-E_{0}\right)-D_{0}=B P_{R}\left(t_{\text {on }}-t_{0}\right)-D_{0}
$$

ただし $E_{0}=P_{R} t_{0}$ である.（2)式を用いて検討した結 果, 定数 $C$ を用いて係数 $B$ を,

$$
B=C V_{R}
$$

とへッドの印加電圧 $V_{R}$ に比例していると解釈するこ とにより，印加電力 $P_{R}$ をパラメータとして測定した

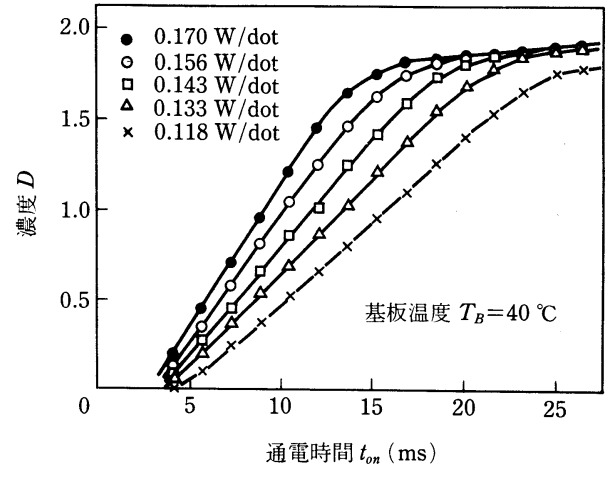

図 2 濃度の印加電力依存性

Supply power dependency of optical density.

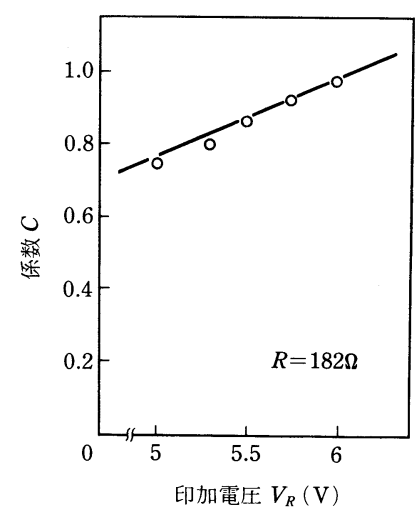

図 3 係数 $C$ と印加電圧 $V_{R}$ の関係 Supply voltage dependency of density sensitivity.

複数の濃度特性曲線のどの直線部分の濃度 $D$ をも計 算できることが判明した。すなわち，（3)式を(2)式 に代入して,

$$
D=C V_{R}\left(E-E_{0}\right)-D_{0}
$$

(4) 式から, この方式の印写濃度は, 感熱へッドの 発熱ドットへの入力エネルギーと, 印加電圧の積に比 例するといえる.すなわち, プリンタの設計において は, 発熱体への印加電圧 $V_{R}$ を可能な限り大きくして 印加電力を大きくし, パルス印加時間を短縮するの が, 所要印刷時間の短縮および高効率印画の両面から 有利なことが判明した. 発熱体への入力エネルギーを 一定とし, 係数 $C$ と印加電圧 $V_{R}$ の関係として図 2 を書き直したものを図 3 に示す。

\section{3 ヘッド基板温度と印写の濃度}

連続して何枚もの印画を行うと, 画面全体の濃度が 安定せず, どんどん濃くなっていく現象が見受けられ た。この現象は, 印写環境温度の上昇によるものと推 定し, 感熱へッドの基板温度 $T_{B}$ （アルミナ基板裏面 で測定）をパラメータとして濃度特性を測定した。実 


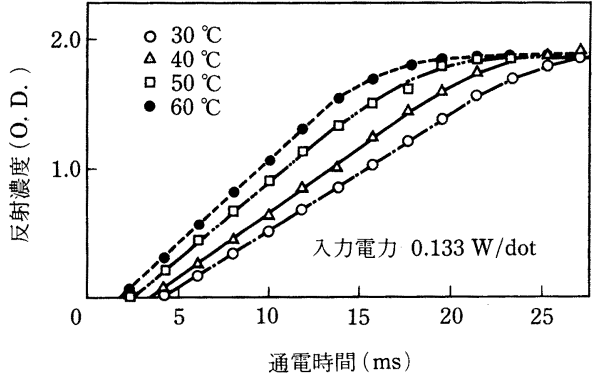

図 4 濃度の基板温度依存性

Base temperature dependency of optical density.

測例を図 4 に示す．基板温度 $T_{B}$ が上昇するにつれて 比例定数 $C$ は大きくなり, 常温での基板温度 $T_{0} に$ 対する基準值 $C_{0}$ を用いて次の実験式が得られた。

$$
C=\alpha\left(T_{B}-T_{0}\right)+C_{0}
$$

$\alpha$ は比例定数で, 図 4 に示した例では $\alpha \fallingdotseq 0.012 て ゙$ あった.この場合, 感熱ヘッドの通電時間として, 例 えば $10 \mathrm{~ms}$ という一定の值を印加しても, 基板温度 が $30^{\circ} \mathrm{C}$ または $60^{\circ} \mathrm{C}$ であると濃度は各々 $0.5,1.1$ と 約 2 倍も違った值となる。この違いは，本試作のビデ オプリンタのごとく, 制御濃度範囲 $0 \sim 1.8$ を 64 階調 に分割して連続階調制御をする場合は約 20 階調の階 調差に相当することになり，無視できない。一方，印 画中は感熱ヘッドで平均数十 W の電力が消費される ので，1枚の画像を印画している間に数 ${ }^{\circ} \mathrm{C}$, 多数枚の 画像を連続して印画する間に数十 ${ }^{\circ} \mathrm{C}$ も基板温度が上 昇することになり，何らかの補正手段が必須である． 具体的な手段として, 基板温度 $T_{B}$ の上昇をヒートシ ンクおよび強制空冷により一定值に抑え，残りの濃度 差を(3) 式と (5) 式を対応させることにより印加電圧 に䚻還させる方法などがある。この場合, 基板温度 $T_{B}$ の $15^{\circ} \mathrm{C}$ の上昇に対し, 印加電圧 $V_{R}$ を約 $1 \mathrm{~V}$ の 割合で下げるよう制御して, 基板温度に依存しないほ ぼ一定の濃度特性が得られる。

\section{4 感熱ヘッドの発熱温度と濃度予測}

以上行った濃度 $D$ と印加電圧 $V_{R}$, 基板温度 $T_{B}$ 等 との関係の検討は，プリンタの設計という意味では見 通しが良いが, 現象の物理的理解という観点からは遠 い。そこで，昇華過程に直接関連する感熱へッドの発 熱状態を測定し，上記検討結果と比較考察することに より濃度予測する手法を検討した。ヘッドの発熱状態 は赤外線温度計を用い, 感熱ヘッド単体の空印字状態 を非接触で測定しだ.

感熱ヘッドの発熱部分の構造を図 5 に, 通電時間に 対する発熱中央部表面の温度 $T$ のプロファイル実測 值例を図 6 に示す。このプロファイルは，通電時間が

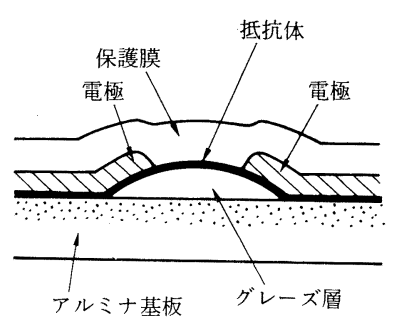

図 5 感熱ヘッドの断面図 Cross sectional view of a thermal head.

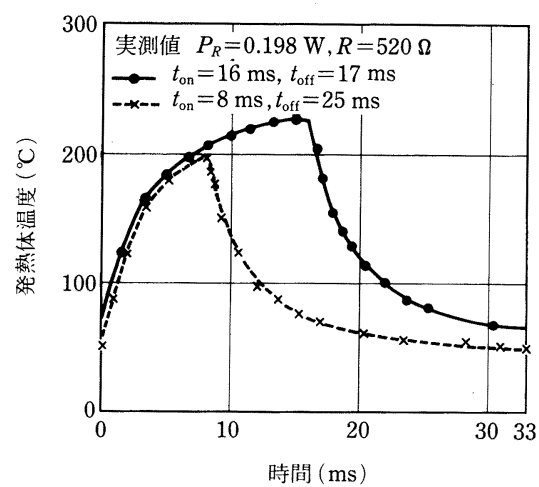

$t_{\mathrm{on}}:$ 通電時間, $t_{\mathrm{off}}:$ 切電時間, $t_{\mathrm{on}}+t_{\text {off }}=33 \mathrm{~ms}$ (周期, 一定)

図 6 発熱温度プロファイルの一例

Temperature profile of a heating element.

数十 ms より短い場合, 微小物体に対する非定常熱伝 導6) と考えて導いた下式とよく一致した。すなわち， 温度 $T$ はヘッドに通電を行っている昇温時には,

$$
T=T_{\infty}-\left(T_{\infty}-T_{L}\right) e^{-\tau_{1} t}
$$

また通電を終了した後の降温時は,

$$
\begin{aligned}
& T=T_{L}+\left(T_{P}-T_{L}\right) e^{-\tau_{2}(t-t o n)} \\
& \text { (ただし } \left., t>t_{\text {on }}\right)
\end{aligned}
$$

の 2 式で表すことができる。ここに， $t$ は時間 $(\mathrm{sec})$ $T_{\infty}, T_{L}$ は各々定常状態における発熱の収束温度と最 低温度, $t_{o n}$ は通電時間, $T_{P}$ は $t_{o n}$ 秒通電した時点で の発熱温度, $\tau_{1}, \tau_{2}$ は, 各々通電時および切電後の 時定数である. 本検討に用いた感熱へッドの場合，実 測值より，ほぼ $\tau_{1} \fallingdotseq \tau_{2} \fallingdotseq 300$ と求められる， $\tau_{1} ， \tau_{2}$ を ヘッドの構造および熱物性值から計算 ${ }^{6}$ により推定す ると約 275 となり，ほほ実測值に合っている。

定常状態の収束温度 $T_{\infty}$ は, 実測結果より,

\footnotetext{
*昇華に寄与する熱は, 厳密には感熱へッドの空印字の状態ではな く、インク紙等の紙の接触した状態で考え杖ばならない。しかしな がら, 受像紙の基紙部分の断熱性が大きいこと, インク紙等の熱容 量が小さいことなどから, 有限要素法を用いて計算によりシミュレ 一トした限りでは, 接触した状態との温度差は最大数十 ${ }^{\circ} \mathrm{C}$ 程度で ある. 本報告では実験で測定し易い空印字状態で議論を進め, 最後 に実験式（(11)式）の係数に含めて, 温度差により生ずるずれ分を 実験的に補正することを試みた。
} 


$$
T_{\infty}=T_{B}+\frac{1}{C_{1}} P_{R}=T_{B}+\frac{1}{C_{1}} \cdot \frac{V_{R}^{2}}{R}
$$

の実験式にまとめることができる，すなわち，感熱へ ッドの基板温度 $T_{B}$ と印加電力に比例する項の和で表 すことができる．図7に示した実測值の例では，放熱 係数 $C_{1}$ は約 $1 \mathrm{~mW} /{ }^{\circ} \mathrm{C}$ であり, 印加パルスのデュー ティ比に起因する基板温度 $T_{B}$ の発熱部付近での変化 を補正すると, 印加電力 $P_{R}$ が $0.5 \mathrm{~W} / \mathrm{dot}$ 以下の領 域での実測值とのずれは数\%以下であった.

次に, 感熱へッドからインク紙および受像紙への注 入熱量を求める。まず, 単位時間あたりの感熱ヘッド から紙への流入熱量 $Q(\mathrm{~J} / \mathrm{sec})$ は, 次式で表され る.

$$
Q=\beta_{1} \Delta T
$$

ここに, $\beta_{1}$ は系の熱伝導率および寸法等により定 まる定数, $\Delta T$ は紙とヘッドの温度差であり, 発熱体 の温度 $T$ と, 環境の温度 $T_{E}$ の差 $\left(\Delta T=T-T_{E}\right)$ と 考えられる。すなわち, 紙は印写ごとに未印写部分が 紙送り動作により供給されるので, その温度はほぼ $T_{E}$ に等しく, かつ通電時間が数十 $\mathrm{ms}$ と短いので系 をほほ断熱と考えて良い。さて，この熱量 $Q$ のうち， 実質的に昇華に寄与する熱量 $Q_{e}(\mathrm{~J} / \mathrm{sec})$ は, 近似的 に昇華性染料が温度 $T_{N}$ で昇華を開始すると考えて

$$
Q_{e}=\beta_{1}\left(T-T_{N}\right)=\beta_{1} \Delta T_{e} \text {, ただし } T>T_{N}
$$
と表す。昇華に係わる総熱量 $P_{e}(\mathrm{~J})$ は, $Q_{e}$ の時間積 分で表せるから, 図 6 に示した感熱ヘッドの温度プロ ファイルの仮想した昇華開始温度以上の部分の面積と して求められる. 画像を印写する場合, 通電時間のデ ユーティー比が大きく, かつヘッドは連続パルス列で 駆動されるため温度プロファイルの立ち上りと立ち下 りの時定数 $\tau_{1}, \tau_{2}$ はほぼ等しくなり, 近似的に,

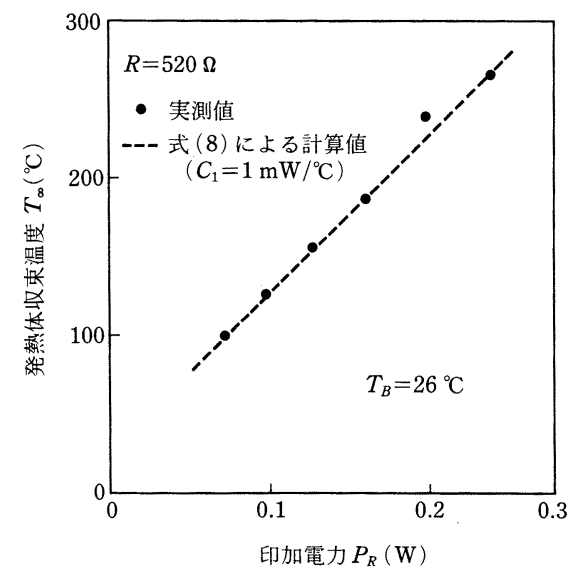

図 7 発熱体の収束温度

Finish temperature of a heating element.

$$
P_{e}=\beta_{1} \Delta T_{h} t_{o n}, \text { ただし } \Delta T_{h}=T_{P}-T_{N}
$$
と表せる。

図 8 に,この熱エネルギー $P_{e}$ を用いて印写の濃度 $D$ を予測しうる可能性を検討するための実験結果を 示す. 同図 (a) は, 発熱体への印加電力と通電時間 $t_{\text {on }}$ を変数として濃度 $D$ を測定した例である. 同図 (b)は, この測定結果と (10)式の対応を調べるため に, 測定值を整頓して作図し直したものである。すな わち, 同図 (b)の横軸は, (10)式の係数 $\beta_{1}$ を形式的

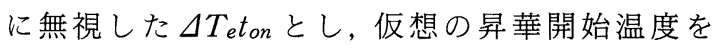
$120^{\circ} \mathrm{C}$ とした.このようにした結果, 感熱ヘッドから 紙に注入される熱エネルギー量 $P_{e}$ と濃度 $D$ の間に は密接な関係があり, これは次式のように表せること がわかった。

$$
D=\beta_{2} \Delta T_{h} t_{o n}-\beta_{3}
$$

ただし $\beta_{2}, \beta_{3}$ は定数で, この場合 $\beta_{2}$ は約 $1.2, \beta_{3}$ は 約 0.05 である. (11) 式を(10)式と対応させるため, 定数 $\beta_{4}$ (ただし $\left.\beta_{4}=\beta_{2} / \beta_{1}\right)$ を用いて形式的に書き改め ると下式のようになる.

$$
D=\beta_{4} \beta_{1} \Delta T_{h} t_{o n}-\beta_{3}=\beta_{4} P_{e}-\beta_{3}
$$

すなわち, 濃度 $D$ は熱エネルギー量 $P_{e}$ に比例する 項とオフセット項の和で予測できることが実験的に判 明した。

\section{5 感熱ヘッドとドラムの当接圧}

感熱ヘッドとドラムの当接条件によって, ヘッド,

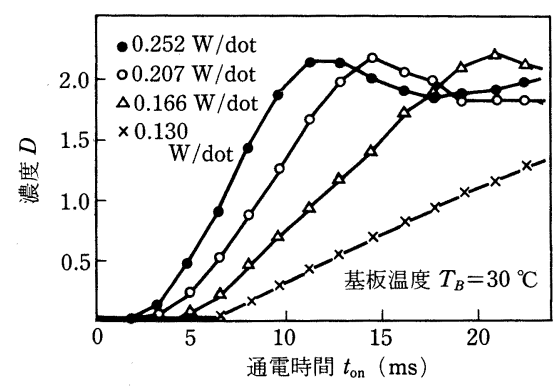

(a) 反射濃度特性実測值

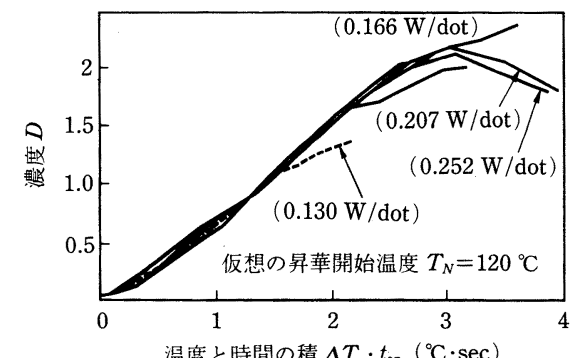

温度と時間の積 $\Delta T_{\mathrm{e}} \cdot t_{\mathrm{on}}\left({ }^{\circ} \mathrm{C} \cdot \mathrm{sec}\right)$

（b）紙への注入熱エネルギー量対濃度特性

図 8 紙への注入熱エネルギー量による濃度予測 Density inference from injection thermo energy. 
インク紙, 受像紙, ドラム各々の接触条件が変わり, (図 1 参照) 熱の通過率が変化するので, 充分な発色濃 度が得られなかったり，1枚の画像の中に濃度むらが 生じたりする．この関係を検討するために, 図 9 に示 すようにへッドとドラムの関係を剛性平板とこれに接 する半径 $r$ の弾性体円柱の接触? と考えた。ヘッドの 押付荷重を $p$ とすると, 接触面の幅（ニップ幅） $2 b$ は,

$$
\begin{aligned}
& 2 b=4(r k p / l)^{1 / 2} \\
& k=\left(1-\nu^{2}\right) / \pi e
\end{aligned}
$$

ここに, $l, \nu, e$ は各々ヘッドとドラムの接触長, ドラムのポアソン比, ゴムの硬度 $H_{s}$ から求まるドラ ムの弾性係数である. また, 接触面における最大当接 圧 $q_{\max }$, および当接圧 $q$ の分布は,

$$
\begin{aligned}
& q_{\max }=\left(1 / \pi^{2} \times 1 / r \times p / k l\right)^{1 / 2} \\
& q=q_{\max }\left(1-x^{2} / b^{2}\right)^{1 / 2}
\end{aligned}
$$

で与えられる。ここに $x$ はヘッドの取付け位置ずれ

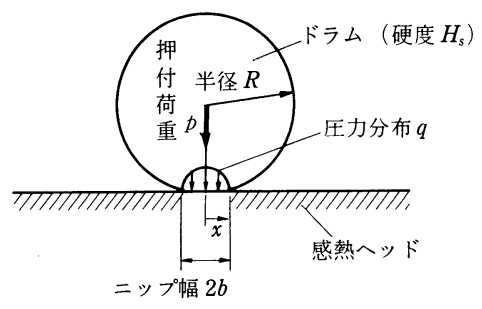

図 9 感熱へッドとドラムの当接モデル Analysis model for thermal head vs. drum contact.

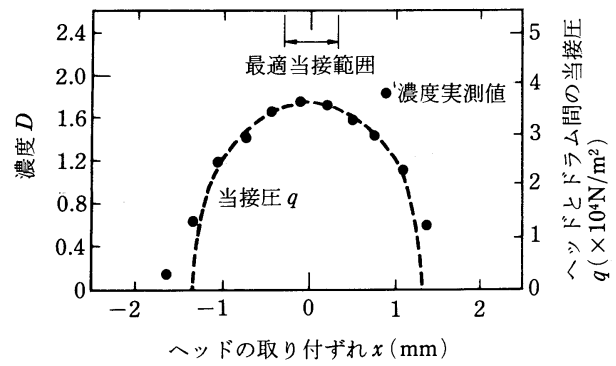

図 10 濃度のヘッド取付位置依存性 Thermal head positioning dependency.

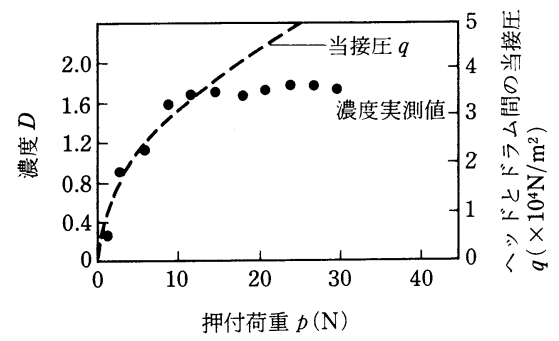

図 11 濃度の押圧荷重依存性 Head-drum pressure dependency.
に相当する接触幅方向の変位である.

図 10, 図 11 に各々ヘッドの取付け位置ずれ，およ び押付荷重に対するへッドとドラムの当接圧を示す． 図中には, 各々の場合の濃度 $D$ の実測值を併せて記 入してある.いずれの場合にも, 濃度 $D$ と当接圧 $q$ はよく対応することが判明した。 ただし, 当接圧が低 くなるにつれて濃度 $D$ のばらつきが大きくなると共 に, 発色形状が発熱ドット形状と対応せず, 発色が不 安定になる傾向が見うけられた。

\section{3. カラーハードコピー装置の試作}

\section{1 性能仕様の設定}

電子スチルカメラの性能は, 撮像部の性能と, 記録 媒体であるビデオフロッピーの性能により定まる．こ れらのうち, ビデオフロッピーの性能仕様は統一規格 化されて扔り ${ }^{8)}$, 垂直走查線数は現行のテレビ方式に 合致した 525 本, 水平解像度は約 $350 \mathrm{TV}$ 本である. したがって，カラーハードコピー装置の性能は，ハー ドコピー化する段階での性能劣化を招かぬよう，この 数值以上の性能を有する必要がある ${ }^{97}$.

一方, 印画結果は, 明視距離でほぼ写真様の解像感 を有させるのが好ましいから, 解像度を数本 $/ \mathrm{mm}$ 以 上とし階調特性も写真に準ずる調子再現特性でなけれ ばならない ${ }^{10)}$.

検討の結果, 上記両方の要求をほぼ満たすものとし て, 各色の階調数を 64 レベル, 分解能を 6 本 $/ \mathrm{mm}$ と した．映像信号の標本化は $10.8 \mathrm{MHz}$, 画像の水平方 向表示率を約 $90 \%$ とし, 印写ライン数を 512 とした. したがって, 印画サイズは $80 \times 98 \mathrm{~mm}$, 画素数は $480(\mathrm{~V}) \times 512(\mathrm{H})=$ 約 246,000 個である.

\section{2 装置の構成}

カラービデオコピー装置試作機の構成を図 12 に示 す. 信号前処理部で AGC, 色補正, 輪郭補正等の信 号処理された信号は $\mathrm{A} / \mathrm{D}$ 変換され, RGB フレーム メモリーに記憶され，各色毎に感熱ラインヘッドに印 加するデー夕を格納するためのラインメモリーに転送 される。転送は画像信号の 1 垂直ライン毎に行われ る、転送レートは，テレビ信号の 1 垂直周期に同期さ せ, 1 フレーム周期 $(33 \mathrm{~ms})$ に 1 印写ライン分のデー 夕 480 個を転送し，印写するようにした。昇華性染料 を塗付したカラーインク紙は, 黄, マゼンタ, シアン の3色面順次ロール化してカセットに収納されてい る.したがって, ドラムに巻付けられた受像紙が 3 回 転する間に 3 色の印写が行われ，カラープリントが得 られる. 図 13 に各色インク紙の濃度特性実測值を示 す. 各色の印写は, 各濃度特性の非直線性と撮像系の 


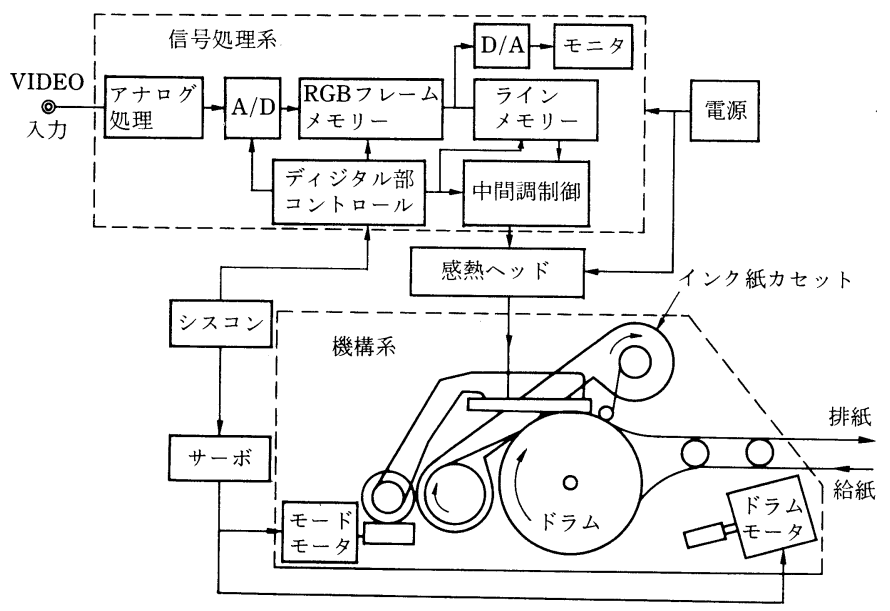

図 12 カラービデオコピー装置の構成

Construction scheme of a color video copy equipment.

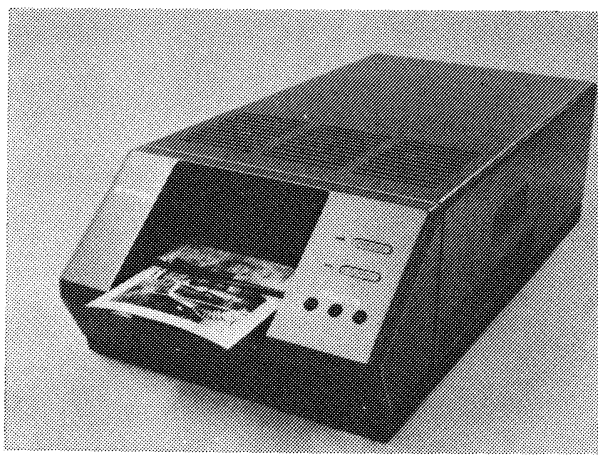

写真 1 試作機の外観

The proto-type of color video copy equipment.

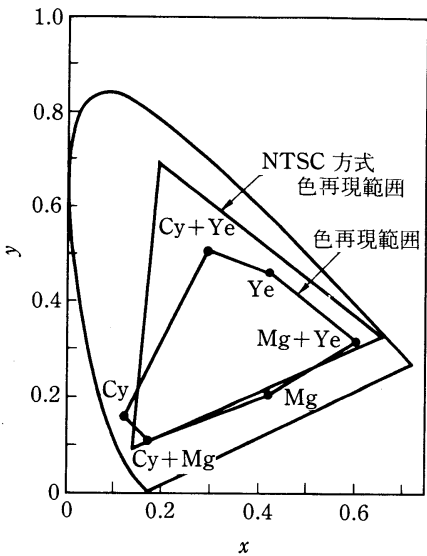

図 14 色再現範囲

Color reproductive area.

ガンマ特性を補正した後に行われる。

写真 1 に試作機の外観を示す．プリント時間は，印 写に要する時間 $1 / 30 \times 512$ ライン $\times 3$ 色 $=51.2$ 秒に

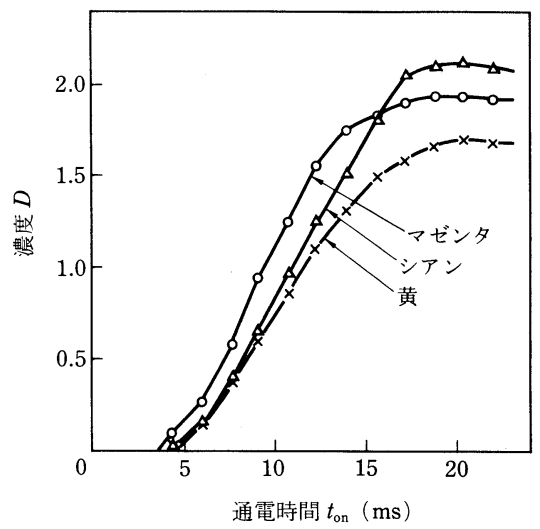

図 13 昇華性染料インクシートの濃度特性 Optical density of sublimation dye ink sheet.

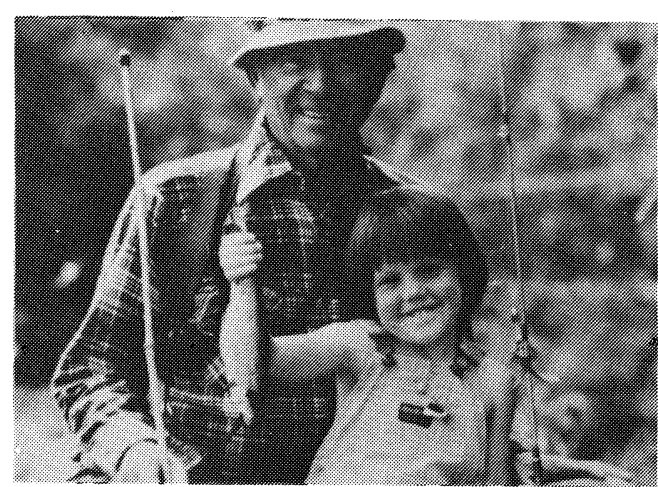

写真 2 印画サンプル A printed sample.

加えて, 給排紙等の所要時間を含めて約 1 分である. 写真 2 に試作したカラービデオ装置の印画例を示す. 前述したように，階調数を各色 64 レベルとしたので， 通常の画面では $\mathrm{A} / \mathrm{D}$ 変換の量子化に由来する擬似輪 郭は見受けられず，アナログ的な連続階調表現が得ら れた。印画の発色領域は，図14 に示すように通常の 印刷に匹敵しており，色の再現性も良い。

\section{4. むす び}

昇華性染料を用いた電子スチルカメラ用カラーハー ドコピー装置の試作につき, 主に安定な連続階調表現 の観点から実験, 解析した結果を述べた。試作装置の 印画画質は, 解像度, 各色の調子再現共にモニタテレ ビ画面にほぼ対応したものであった。一方, 印画サイ ズを手札判相当の $80 \times 98 \mathrm{~mm}$ とし, 分解能を 6 本/ $\mathrm{mm}$ としたので, 明視距離では絵素構造, 走査線構造 も目立たず，ピクトリアルハードコピーとして好まし い解像度と階調特性が得られた。 
このカラーハードコピー装置は, 電子スチルカメラ 用にとどまらず，テレビ放送受信，ビデオカメラ， VTR 等の動画信号源から入力されるビデオ信号の八 ードコピー装置, 工業計測機, 医療機器等への応用等 の幅広い用途が考えられる.

最後に本研究をご指導, ご支援, ご協力いただいた 多くの方々, 特に日立製作所日立研究所 堀康郎主管 研究員, 機械研究所 松野順一研究員, 東海工場 佐藤 勝也部長に深く感謝します.

(昭和 60 年 1 月 29 日受付, 昭和 60 年 7 月 30 日最終受付)

\section{〔参 考 文 献〕}

1) Kihara, et al: "The Electronic Still Camera a New Concept in Photography", IEEE Trans., CE-28, 8, pp. 325 -331 (Aug., 1982)
2) Hanma, et al : "A Electronic Still Camera Technology", IEEE Trans., CE-30, 8, pp. 402-407 (Aug., 1984)

3）大野信ほか：“小特集 テレビ画像のハードコピー”, テレビ 誌, 37, 7, pp. 520-558 (July, 1983)

4) Masuda, et al: "Color Video Picture Printer", IEEE Trans., CE-28, 8, pp. 226-232 (Aug., 1982)

5) 田口ほか: “昇華転写形感熱記録体”, 第 14 回画像工学コン ファレンス論文集 8-4, pp. 197-200（1983）

6) 機械学会編：“伝熱工学資料 (改訂第 3 版)”, 機械学会, p. 162 (1975)

7) 平修二：“現代弾性力学”, オーム社, p. 197 (1975)

8）水島：“電子スチルカメラ懇談会の活動とスチルビデオフロ ッピー規格”, テレビ学技報（回路, 方式), 8, 35, TEBS 1001 (Dec., 1984)

9）半間ほか：“電子スチルカメラ用ハードコピー装置”, 同上, TEBS 100-3 (Dec., 1984)

10）奥田ほか：“TV 画像ハードコピー化用プリンターにおける 信号処理”, 第 14 回画像工学コンファレンス論文集 8-5, p. 201 (1983) 